\title{
Comparison of Anastomosis Safety in Colonic Dissections Using Scalpel, Scissors and Cautery in Rats: Experimental Study
}

\author{
Sıçanlarda Bistüri, Makas ve Koter Kullanılarak Kolon Diseksiyonlarında \\ Anastomoz Güvenliğinin Karşılaştırılması: Deneysel Çalışma
}

\begin{abstract}
(D) Hakan Yiğitbaş¹, (D Candaş Erçetin11, (D) Erkan Yavuz¹, (D) Osman Bilgin Gülçiçek¹, (D) Ali Solmaz¹, (D) Kamil Özdoğan1, (D) Aytaç Biricik1, (D) Aslı Kahraman Akkalp², (D) Hafize Uzun³, (D) Fatih Çelebi1, (D) Atilla Çelik1

${ }^{1}$ University of Health Sciences Turkey, Bağcılar Training and Research Hospital, Clinic of General Surgery, İstanbul, Turkey

2University of Health Sciences Turkey, İzmir Katip Çelebi University, Atatürk Training and Research Hospital, Clinic of Pathology, İzmir, Turkey 3İstanbul University-Cerrahpaşa, Cerrahpaşa Faculty of Medicine, Department of Medical Biochemistry, İstanbul, Turkey
\end{abstract}

\section{Abstract}

Objective: Postoperative anastomotic leakage is still an issue in modern surgery. Re-hospitalization due to postoperative anastomosis leakage prolongs hospital stay and re-operations increase the cost. There is still no consent on how to dissect the intestines. The objective of the present study is to analyze the safety of colonic anastomoses after dissections using scalpel, scissors and cautery in rats.

Method: There were 4 groups of 32 Wistar Hannover adult rodents. Each group consisted of 8 animals: group 1: sham, group 2: scalpel, group 3: scissors, group 4: cautery. Anastomosis was done over a single layer. Bursting pressure (BP) was measured at day 7. Tissue and blood samples were taken for the evaluation of biochemical and histopathological parameters.

Results: Statistically significant disparity was seen among the sham, scalpel, scissors and cautery groups regarding the mean BP average, mean hydroxyproline levels and fibrosis distributions.

Conclusion: Cautery is the best choice for hemostasis; however, when considering tissue healing, scalpel and the scissors were found to be safest alternatives.

Keywords: Anastomotic leak, colonic dissection, hydroxyproline, rats, tissue healing

\section{Öz}

Amaç: Postoperatif anastomoz kaçağı modern cerrahide hala bir sorundur. Postoperatif anastomoz kaçağı nedeniyle yeniden hastaneye yatış hastanede kalış süresini uzatır ve yeni ameliyatlar maliyeti artırır. Bağırsakların nasıl diseke edileceğine dair hala bir fikir birliği yoktur. Bu çalışmanın amacı, sıçanlarda bistüri, makas ve koter kullanarak diseksiyon sonrası kolon anastomozlarının güvenliğini karşılaştırmaktır.

Yöntem: Otuz iki yetişkin Wistar Hannover sıçanı rastgele olarak her biri 8 hayvan içeren 4 gruba ayrıldı: grup 1: sham grubu, grup 2: bistüri grubu, grup 3: makas grubu, grup 4: koter grubu. Anastomoz tek tek sütürler ile tek kat üzerinden yapıldı. Patlama basıncı 7. günde ölçüldü. Biyokimyasal ve histopatolojik parametrelerin değerlendirilmesi için doku ve kan örnekleri alındı.

Bulgular: Sham, bistüri, makas ve koter grupları arasında patlama basıncı ortalaması, ortalama hidroksiprolin seviyeleri ve fibroz dağılımları açısından istatistiksel olarak anlamlı bir fark tespit edildi.

Sonuç: Hemostaz için koter en iyi seçimdir, ancak doku iyileşmesi düşünüldüğünde, neşter ve makas en güvenli alternatifler olarak bulunmuştur.

Anahtar kelimeler: Anastomoz kaçağı, doku iyileşmesi, hidroksiprolin, kolon diseksiyonu, sıçan

Address for Correspondence: Hakan Yiğitbaş, University of Health Sciences Turkey, Bağcılar Training and Research Hospital, Clinic of General Surgery, İstanbul, Turkey

E-mail: drhyigitbas@yahoo.com.tr ORCID: orcid.org/0000-0002-9545-2231 Received: 25.08.2020 Accepted: 12.10.2020

One of the authors of this article (AÇ) is a member of the Editorial Board of this journal. He was completely blinded to the peer review process of the article.

Cite this article as: Yiğitbaş H, Erçetin C, Yavuz E, Gülçiçek OB, Solmaz A, Özdoğan K, Biricik A, Kahraman Akkalp A, Uzun H, Çelebi F, Çelik A. Comparison of Anastomosis Safety in Colonic Dissections Using Scalpel, Scissors and Cautery in Rats: Experimental Study. Bagcilar Med Bull 2021;6(1):14-19.

${ }^{\circ}$ Copyright 2021 by the Health Sciences University Turkey, Bagcilar Training and Research Hospital Bagcilar Medical Bulletin published by Galenos Publishing House. 


\section{Introduction}

Postoperative anastomotic leakage is seen in the intestinal and colonic operations at the rates of $1 \%$ and $0.5 \%-30 \%$, respectively (1). $1 \%$ of the patients who were previously known to have an intestinal anastomosis are re-hospitalized due to postoperative anastomosis leakage and in addition, their hospital stay is prolonged. Secondary interventions to such patients are the leading problems of gastrointestinal surgery due to their difficulties. In a study involving 6,174 patients, Hammond et al. (2) reported that hospital stay after colonic anastomosis increased by 7.3 days and the average cost was $\$ 24,129$.

The objective of the present study is to analyze the safety of colonic anastomoses after dissections using scalpel, scissors and cautery in rats.

\section{Materials and Methods}

\section{Experimental Design}

In this study, 32 adult Wistar Hannover rats (İstanbul Bağcilar Experimental Research and Skills Development Center, BADABEM) with an average weight of 300-500 grams were used. All animals were kept at room temperature of 22 ${ }^{\circ} \mathrm{C}$ for 12 hours in a dark/light cycle. Animals in all groups were fed freely with rat feed containing $21 \%$ protein. Fresh drinking water was given daily. All subjects were kept in separate cages in groups. The study was approved by the Local Ethics Committee of University of Health Sciences Turkey, Bağcılar Training and Research Hospital (project no: 2013-28). Patient consent form was not required due to the nature of the study.

\section{Study Groups}

Rats were randomly divided into 4 groups, each containing 8 animals:

Group 1, sham group,

Group 2, scalpel group, large intestine transection with scalpel,

Group 3, scissors group, large intestine transection group with scissors,

Group 4, cautery group, large intestine transection group with cautery.

\section{Operative Procedure}

The rats were anesthetized with ketamine hydrochloride (50 $\mathrm{mg} / \mathrm{kg}$, Ketalar; Farke-Davis, Istanbul, Turkey) and xylazine (10 mg/kg, Rompun: Bayer, Istanbul, Turkey) anesthesia, asepsis with $10 \%$ povidone iodine solution, and following the provision of antisepsis, a $3 \mathrm{~cm}$ incision was made in the abdominal median line under sterile conditions.

In Group 1, the descending colon was manipulated. The abdomen was closed without anastomosis.

In Group 2, the descending colon was cut with a scalpel $2 \mathrm{~cm}$ proximal to the peritoneal reflection in the scalpel group and anastomosed end-to-end over a single layer with 5.0 poli (glicolid-co-lactid) (Pegelak, Doğusan, Istanbul Turkey) suture.

In Group 3, the scissors group, the descending colon was cut with scissors $2 \mathrm{~cm}$ proximal to the peritoneal reflection and end-to-end anastomosis with 5.0 poli (glicolid-colactid) suture over a single layer was performed.

In Group 4, the cautery group, the descending colon was cut with cautery $2 \mathrm{~cm}$ proximal to the peritoneal reflection and end-to-end anastomosis with 5.0 poli (glicolid-colactid) suture over a single layer was done.

All procedures were performed by the same surgeon. 10 $\mathrm{mg} / 1 \mathrm{~mL}$ paracetamol was administered intraperitoneally for analgesia before the incision was closed. Abdominal incisions were closed in two layers with 3.0 interrupted silk sutures (Doğusan, Istanbul, Turkey). Feeding was started immediately after the operation. On day seven, all animals were sacrificed. None of the rats experienced significant weight loss between the initial surgery and sacrification.

\section{Bursting Pressure Measurement}

The anastomosis line was resected as an anterior block, and the $2 \mathrm{~cm}$ distal and $2 \mathrm{~cm}$ proximal of the line were clamped. $0.9 \% \mathrm{NaCl}$ stained with methylene blue was infused into the intestine at a rate of $2 \mathrm{~mL} / \mathrm{min}$. Intra-segment pressure was monitored. The pressure value at which the leak was seen in the anastomosis line was recorded as BP.

\section{Hydroxyproline Analysis}

The samples for hydroxyproline $(\mathrm{H})$ levels were weighed, cut into small pieces, and homogenized in a phosphate buffer to yield a $20 \%$ homogenate. Aliquots of the homogenate were added to an equal volume of $6 \mathrm{~N}$ hydrochloric acid, and hydrolyzed in Teflon-capped vials at $102^{\circ} \mathrm{C}$ for 16 hours. The $\mathrm{H}$ content of the tissue hydroxylates was determined spectrophotometrically by using the standard addition method developed by Kivirikko et al. (3) (Hypopronosticon, Kit lot/ch. B:E 92401, Organon Teknika., Boxtel, Holland). Results were expressed in milligrams, such as in $\mathrm{H} / 100 \mathrm{mg}$ (wet weight). 


\section{Histological Analysis}

The degree of fibrosis of hematoxylin-eosin-stained preparations was evaluated under a light microscope using a scale adjusted for the severity of fibrosis. (0: minimal, 1 : slight, 2: moderate, 3: severe).

\section{Sacrifice and Necropsy}

No deaths related to peritonitis or any complications of anastomosis leakage developed. At autopsy, none of the rats had any ileus or evidence of anastomosis insufficiency (feces within the abdominal cavity or abscess).

All groups were sacrificed with high dose ketamine anesthesia on postoperative $7^{\text {th }}$ day and blood samples of all animals were taken by intracardiac puncture. Colonic anastomosis lines of all animals were removed, BP values of anastomosis line were measured.

Anastomosis lines were resected unblock $1 \mathrm{~cm}$ distal and proximal. The anastomosis line was divided by mesenteric borders. One segment was frozen in liquid nitrogen and stored at $-80{ }^{\circ} \mathrm{C}$ for $\mathrm{H}$ analysis, the other segment was placed in formaldehyde solution for histopathological examination.

\section{Statistical Analysis}

Statistical analysis was performed by NCSS (Number Cruncher Statistical System) 2007 Statistical Software (Utah, USA). Descriptive statistical methods (mean, standard deviation, median, interquartile range) were used in the evaluation of the data, as well as Dunn's multiple comparison test in the Kruskal-Wallis test subgroup comparisons, Mann-Whitney U test in the comparison of the paired groups, and chi-square test in the comparison of the qualitative data. Results were evaluated at $\mathrm{p}<0.05$ level of significance.

\section{Results}

There was a statistically significant difference among the mean sham, scalpel, scissors and cautery groups ( $p=0.0001$ ) in BP average. The mean of the sham group was significantly higher than the mean of the scalpel, scissors and cautery groups $(\mathrm{p}=0.001)$ (Table 1$)$. No statistically significant difference was found between scalpel cautery groups $(\mathrm{p}=0.748)$ (Table 2$)$.

There was a statistically significant difference among the mean H levels of Sham, Scalpel, Scissors and Cautery groups $(\mathrm{p}=0.041)$. The mean $\mathrm{H}$ of the sham group was found to be significantly higher than the mean of scalpel, scissors and cautery groups ( $\mathrm{p}=0.049, \mathrm{p}=0.021$ ). No significant difference was observed between scalpel and scissors groups and also between scalpel and cautery groups ( $p>0.05$ ) (Table 2).

There was a statistically significant difference among fibrosis distributions of groups ( $\mathrm{p}=0.0001$ ). The presence of minimal fibrosis was significantly higher in the Sham group than in the Scalpel, Scissors and Cautery groups.

When the scalpel, scissors and cautery groups were compared, no significant difference was found in the distribution of fibrosis (Table 3 ).

Table 1. Bursting pressure and tissue hydroxyproline levels

\begin{tabular}{llll} 
& & Pressure (mm/Hg) & Hydroxyproline (../100 mg) \\
\hline Sham group & Median (IQR) & $290(286.25-300)$ & $7657.97(1715.49-11764.28)$ \\
Scalpel group & Median (IQR) & $10(0-148.5)$ & $725.2(114.545-2385.8)$ \\
Scissors group & Median (IQR) & $120(66.25-166.25)$ & $1304.32(1141.3-2478.66)$ \\
Cautery group & Median (IQR) & $50(2.5-68.75)$ & $656.68(368.51-774.09)$ \\
& $\mathbf{p}$ & $\mathbf{0 . 0 0 0 1}$ & $\mathbf{0 . 0 4 1}$ \\
\hline
\end{tabular}

IQR: Interquartile range, $p<0.05$ level of significance

Table 2. Dunn's multiple comparison test of groups

Dunn's Multiple Comparison test

Sham group/Scalpel group

Sham group/Scissors group

Sham group/Cautery group

Scalpel group/Scissors group

Scalpel group/Cautery group

Scissors group/Cautery group

$p<0.05$ level of significance
Hydroxyproline (p)

0.021

0.049

0044

0.600

0.916

0.012 
Table 3. Histopathological evaluation of each group

\begin{tabular}{lllllllll} 
Fibrosis & Sham & \multicolumn{3}{c}{ Scalpel } & \multicolumn{2}{c}{ Scissors } & \multicolumn{2}{c}{ Cautery } \\
\hline Minimal & 8 & $100.00 \%$ & 0 & $0.00 \%$ & 0 & $0.00 \%$ & 0 & $0.00 \%$ \\
Mild & 0 & $0.00 \%$ & 1 & $12.50 \%$ & 0 & $0.00 \%$ & 2 & $25.00 \%$ \\
Intermediate & 0 & $0.00 \%$ & 5 & $62.50 \%$ & 3 & $37.50 \%$ & 4 & $50.00 \%$ \\
Severe & 0 & $0.00 \%$ & 2 & $25.00 \%$ & 5 & $62.50 \%$ & 2 & $25.00 \%$ \\
\hline
\end{tabular}

\section{Discussion}

To our knowledge, there is elevated mortality and morbidity rates in case of anastomotic leak or dissociation occur (4). Aforementioned complications occur more frequently in large bowel anastomosis operations. (13\%-69\%) (5). Risk factors for anastomotic leakage are smoking, chronic heart disease, diabetes and obesity (6-8).

Different techniques, materials and agents have been developed throughout years whereas no solution has been overcome yet (9). Some authors covered the anastomosis with different type of meshes but problem is still existing $(10,11)$. Golden standard method for dissecting tissue is scalpel. This way of dissection is simple and low cost; however, it prolonged surgery time due to lack of hemostasis. It has some disadvantages like the lack of hemostasis which prolongs surgery time and risk of unintended injuries (12).

In the past decade, the invention of electrocautery has solved several defects of scalpel (13). Heat energy is used to denature proteins to ensure hemostasis (14), but electrocautery damages the tissue by heat energy (15).

Scalpel cuts are preferred over electrocauter in some studies in which they have fewer infection in wounds with an increase in wound durability $(16,17)$. However, in some studies, no difference for infection rate in wounds is shown for electrocautery and scalpel (18).

Collagen filaments and filament improvement with the submucosal layer are related to the strength of the anastomosis (19). Recovery pursues the sequential states of tissue renovation mostly constructed by growth factors and cytokines (20). Fibrin and fibronectin template pro forma secures and attaches two ends of bowel at the hemostatic phase. Since day 3, temporary matrix evolves with fibroblasts, macrophages and new blood vessels making new granulation tissue (21). Fibroblasts mainly produce collagen (22). On the day 6 and 7 , maximum peak of collagen production emerges, and this is correlated with breaking strength (23). Anastomotic repair and inhibition of submucosal fibers of collagen degradation promote angiogenesis and granulation texture deposition, including non-overlapping, and the acceleration of epithelization improved through different mechanisms (24).

Tissue $\mathrm{H}$ levels and $\mathrm{BP}$ are indirect indicators of anastomotic healing. To determine the level of $\mathrm{H}$ is a decent way for assessing the quantify of collagen texture $(25,26)$.

Beginning at about 5 days, it approaches the normal level while the $\mathrm{H}$ condensation reduces by $40 \%$ and rises from normal level on the 10-14th day (27).

$\mathrm{BP}$ is an indication for the healing process of an anastomosis (28). Because of larger numbers of microorganisms, minimal arteriole nurture, and greater feces quantity, leak in left sided colon anastomosis risk is greater than the other parts (29).

Quality and quantity of newly synthesized collagen target to bring tissue strength to pre-anastomotic levels $(30,31)$. The measurement of $\mathrm{H}$ is a decent parameter of anastomotic healing (32). BP measurement is robustness test of the anastomosis (33).

\section{Conclusion}

Leakage in left-sided colon anastomosis is still a serious complication. The etiology of colonic anastomotic leakage remains unclear. Minimal damage to colonic tissue when dissecting will cause the most acceptable outcomes. Cautery is best for hemostasis but scalpel and scissors dissection have the better results of tissue healing. More research is needed to introduce which way is the best for intestinal healing and to prevent complications.

\section{Acknowledgments}

This work was guarantored by the University of Health Sciences Turkey, Bağcılar Training and Research Hospital Educational Planning and Coordination Committee. A preliminary datum of this project was submitted in the $7^{\text {th }}$ European Multidisciplinary Colorectal Cancer Congress, Amsterdam, 2014 (poster presentation). 


\section{Ethics}

Ethics Committee Approval: The study was approved by the Local Ethics Committee of University of Health Sciences Turkey, Bağcllar Training and Research Hospital (project no: 2013-28).

Informed Consent: Patient consent form was not required due to the nature of the study.

Peer-review: Externally peer-reviewed.

\section{Authorship Contributions}

Concept: H.Y., O.B.G., C.E., K.Ö., A.B., Design: H.Y., O.B.G., A.Ç., F.Ç., H.U., E.Y., Data Collection or Processing: C.E., E.Y., K.Ö., A.K.A., H.U., A.B., H.Y., Analysis or İnterpretation: C.E., F.Ç., A.B., O.B.G, A.Ç., H.U., A.K.A., K.Ö., Writing: H.Y., A.Ç., F.Ç., A.K.A., E.Y.

Conflict of Interest: No conflict of interest was declared by the authors.

Financial Disclosure: Financial support was received from University of Health Sciences Turkey, Bağcılar Training and Research Hospital.

\section{References}

1. Krarup PM, Jorgensen LN, Andreasen AH, Harling H. A nationwide study on anastomotic leakage after colonic cancer surgery. Colorectal Dis 2012;14(10):e661-667.

2. Hammond J, Lim S, Wan Y, Gao X, Patkar A. The burden of gastrointestinal anastomotic leaks: an evaluation on of clinical and economic outcomes. J Gastrointest Surg 2014;18(6):1176-1185.

3. Kivirikko KI, Laitinen O, Prockop DJ. Modifications of a specific assay for hydroxyproline in urine. Anal Biochem1967;19(2):249-255.

4. Verhofstad MH, Hendriks T. Diabetes impairs the development of early strength, but not the accumulation of collagen, during intestinal anastomotic healing in the rat. Br J Surg 1994;81(7):1040-1045.

5. Rolandelli RH, Koruda MJ, Settle RG, Rombeau JL. Effects of intraluminal infusion of short-chain fatty acids on the healing of colonic anastomosis in the rat. Surgery 1986;100(2):198-204.

6. Kruschewski M, Rieger H, Pohlen U, Hotz HG, Buhr HJ. Risk factors for clinical anastomotic leakage and postoperative mortality in elective surgery for rectal cancer. Int J Colorectal Dis 2007;22(8):919-927. (Epub 2007 Jan 27).

7. Vignali A, Fazio VW, Lavery IC, Milsom JW, Church JM, Hull TL, et al. Factors associated with the occurrence of leaks in stapled rectal anastomoses: a review of 1,014 patients. J Am Coll Surg 1997;185(2):105-113.

8. Rullier E, Laurent C, Garrelon JL, Michel P, Saric J, Parneix M. Risk factors for anastomotic leakage after resection of rectal cancer. $\mathrm{Br} \mathrm{J}$ Surg 1998;85(3):355-358.

9. Yesilkaya Y, Soyhan N, Bengisu N, Sen M, Aritas Y. The effects of different suture techniques on collagen metabolism in experimental distal colonic anastomoses. Br J Surg 1985;72(12):987-989.
10. Aysan E, Dincel O, Bektas H, Alkan M. Polypropilen mesh covered colonic anastomosis. Results of a new anastomosis technique. Int J Surg 2008;6(3):224-229.

11. Aysan E, Bektas H, Ersoz F, Sari S, Kaygusuz A. A novel colonic anastomosis technique involving fixed poly-glycolic acid mesh. Int J Clin Exp Med 2010;3(4):341-346.

12. Glover JL, Bendick PJ, Link WJ. The use of thermal knives in surgery: electrosurgery, lasers, plasma scalpel. Curr Probl Surg 1978;15(1):1-78.

13. Gushing H. Electro-surgery as an aid to the removal of intracranial tumors: with a preliminary note on a new surgical current generator by W.T. Bovie, Ph.D, Chicago. Surg Gyn Obstet 1928;47(1928):751-784.

14. Harrington DP. Electrosurgery fact and fiction. Biomed Instrum Technol 1994;28(4):331-333.

15. Rappaport WD, Hunter GC, Allen R, Lick S, Halldorsson A, Chvapil $\mathrm{T}$, et al. Effect of electrocautery on wound healing in midline laparotomy incisions. Am J Surg 1990;160(6):618-620.

16. Hochberg J, Murray GF. Principles of operative surgery. In Textbook of surgery, Sabiston DC, Lyerly HK (editors) 15th ed., Philadelphia: WB Saunders, 1992:253-263.

17. Soballe PW, Nimbkar NV, Hayward I, Nielsen TB, Drucker WR. Electric cautery lowers the contamination threshold for infection of laparotomies. Am J Surg 1998;175(4):263-266.

18. Groot G, Chappell EW. Electrocautery used to create incisions does not increase wound infection rates. Am J Surg 1994;167(6):601-603.

19. Aslan A, Temiz M, Hakverdi S, Polat G, Tumer C, Temiz A, et al. Effect of mesalamine on healing in experimental colon anastomosis: a randomized experimental study. Int J Surg 2008;6(1):40-44. (Epub 2008 Feb 20).

20. Rijcken E, Sachs L, Fuchs T, Spiegel HU, Neumann PA. Growth factors and gastrointestinal anastomotic healing. J Surg Res 2014;187(1):202-210. (Epub 2013 Oct 12).

21. Agren MS, Andersen TL, Mirastschijski U, Syk I, Schiødt CB, Surve V, et al. Action of matrix metalloproteinases at restricted sites in colon anastomosis repair: an immunohistochemical and biochemical study. Surgery 2006;140(1):72-82.

22. Christensen H, Chemnitz J, Christensen BC, Oxlund H. Collagen structural organization of healing colonic anastomoses and the effect of growth hormone treatment. Dis Colon Rectum 1995;38(11):1200-1205.

23. Oxlund H, Christensen H, Seyer-Hansen M, Andreassen TT. Collagen deposition and mechanical strength of colon anastomoses and skin incisional wounds of rats. J Surg Res 1996;66(1):25-30.

24. Øines MN, Krarup PM, Jorgensen LN, Agren MS. Pharmacological interventions for improved colonic anastomotic healing: a metaanalysis. World J Gastroenterol 2014;20(35):12637-12648.

25. Erginel B, Erginel T, Aksoy B, Dokucu AI. Effect of ozone therapy (OT) on healing of colonic anastomosis in a rat model of peritonitis. Balkan Med J 2014;31(3):249-253.

26. Rolandelli RH, Koruda MJ, Setle RG, Rombeau JL. Effects of intraluminal infusion of short-chain fatty acids on healing of colonic anastomosis in rat. Surgery 1986;100(2):198-204.

27. Senol M, Altintas MM, Cevik A, Altuntas YE, Barisik NO, Bildik N, et al. The effect of fibrin glue on the intensity of colonic anastomosis in the presence and absence of peritonitis: an experimental randomized controlled trial on rats. ISRN Surg 2013;2013:1e6, 521413. (Epub 2013 Jan 21). 
28. Kemik O, Adas G, Arikan S, Gurluler YD, Toklu AS, Kapran Y, et al. Evaluation of the effects of hyperbaric oxygen treatment and enoxaparin on left colon anastomosis. An experimental study. Eur Rev Med Pharmacol Sci 2013;17(17):2286-2292.

29. Arikanoglu Z, Cetinkaya Z, Akbulut S, Ilhan YS, Aygen E, Basbug M, et al. The effect of different suture materials on the safety of colon anastomosis in an experimental peritonitis model. Eur Rev Med Pharmacol Sci 2013;17(19):2587-2593.

30. Thornton FJ, Barbul A. Healing in the gastrointestinal tract. Surg Clin North Am 1997;77(3):549-573.
31. Brenner DA, O’Hara M, Angel P, Chojkier M, Karin M. Prolonged activation of jun and collagenase genes by tumour necrosis factoralpha. Nature 1989;337(6208):661-663.

32. Cohen SR, Cornell CN, Collins MH, Sell JE, Blanc WA, Altman RP. Healing of ischemic colonic anastomoses in the rat: role of antibiotic preparation. Surgery 1985;97(4):443-446.

33. Furst MB, Stromberg BV, Blatchford GJ, Christensen MA, Thorson AG. Colonic anastomoses: bursting strength after corticosteroid treatment. Dis Colon Rectum 1994;37(1):12-15. 